\title{
Is COVID-19 a risk factor for invasive pulmonary aspergillosis in critically ill patients?
}

\author{
Berrin $\mathrm{ER}^{1, *}(\mathrm{ID})$ \\ Ahmet Görkem ER ${ }^{2}(I D)$ \\ Gökhan METAN ${ }^{2}$ (ID) \\ Burçin HALAÇLI ${ }^{1}(I D)$ \\ Ebru ORTAÇ ERSOY ${ }^{1}(I D)$ \\ Gülşen HAZIROLAN ${ }^{3}$ (ID) \\ Alpaslan $\mathrm{ALP}^{3}$ (ID) \\ Zeynep SARIBAŞ ${ }^{3}$ (ID) \\ Sevtap ARIKAN \\ AKDAĞLI ${ }^{3}(I D)$ \\ Arzu TOPELi ${ }^{1}$ (ID) \\ Ömrüm UZUN ${ }^{2}$ (ID)
}
${ }^{1}$ Division of Intensive Care, Department of Internal Medicine, Hacettepe University Faculty of Medicine, Ankara, Turkey
${ }^{1}$ Hacettepe Üniversitesi Tıp Fakültesi, İ̧ Hastalıkları Anabilim Dalı, Yoğun Bakım Bölümü, Ankara, Türkiye
2 Department of Infectious Diseases and Clinical Microbiology, Hacettepe University Faculty of Medicine, Ankara, Turkey
${ }^{2}$ Hacettepe Üniversitesi Tıp Fakültesi, Enfeksiyon Hastalıkları ve Klinik Mikrobiyoloji Anabilim Dalı, Ankara, Türkiye
${ }^{3}$ Department of Medical Microbiology, Hacettepe University Faculty of Medicine, Ankara, Turkey
${ }^{3}$ Hacettepe Üniversitesi Tıp Fakültesi, Tıbbi Mikrobiyoloji Anabilim Dalı, Ankara, Türkiye

\begin{abstract}
* This study was presented at $17^{\text {th }}$ National Congress of the Turkish Society of Medical and Surgical Intensive Care Medicine. GM has received honoraria for speaking at symposia and lectures organized by Gilead; Merck, Sharp, and Dohme (MSD); and Pfizer, and he has received travel grants from MSD, Pfizer, and Gilead to participate in conferences, he is a member of advisory comittee of Pfizer and MSD. SAA reports speaker honoraria or travel grant from Astellas, Gilead, and Pfizer outside the submitted work. All other athors have no conflicts of interest.
\end{abstract}

Cite this article as: $\operatorname{Er} B, \operatorname{Er} A G$, Metan $G$, Halaçlı B, Ortaç Ersoy E, Hazırolan G, et al. Is COVID-19 a risk factor for invasive pulmonary aspergillosis in critically ill patients? Tuberk Toraks 2021;69(1):118-120.

\section{Yazışma Adresi (Address for Correspondence)}

\section{Dr. Berrin ER}

Hacettepe Üniversitesi Tıp Fakültesi, Iç Hastalıkları Anabilim Dalı,

ANKARA - TÜRKIYE

e-mail: berrinerkus@gmail.com

OCopyright 2021 by Tuberculosis and Thorax.

Available on-line at www.tuberktoraks.org.com
To the Editor,

Recently, several studies have emphasized the impact of invasive pulmonary aspergillosis (IPA) in COVID-19 (1). Regardless of the presence of underlying pathologies or interventions specified as host factors defined in EORTC/MSG Consensus report, the use of immunosuppressive and immunomodulatory therapies for COVID-19 and the presence of risk factors such as chronic obstructive pulmonary disease in these patients may facilitate development of IPA (2). On the other hand, as influenza was reported as an independent risk factor for developing IPA, a similar situation may occur in COVID19 patients (3). Although diagnosis of IPA is further challenged by reluctance to take lower respiratory tract samples because of increased risk of viral transmission, and radiologically non-specific 
findings in the non-neutropenic patient, it has been shown in a prospective study that with an IPA algorithm developed for COVID-19, the frequency of IPA reached approximately $28 \%$ (4). With an increased mortality and prolonged hospitalization, as reported in the study of White et al., IPA maintains its importance, especially in severely ill patients followed in the intensive care (5).

Our hospital is a referral center with an extensive experience in invasive fungal infections in hemato-oncological patients and our medical intensive care unit has served exclusively to critically ill COVID-19 patients since March 2020. This study was approved by the ethical committee of our hospital. We compared the frequency of invasive fungal infections in patients admitted to the medical intensive care unit in the last six-month period (April 1 2020-September 30 2020; COVID-19 period) with those in the same months in
2019 (pre-COVID-19 period). Galactomannan (GM) index of serum and lower respiratory tract samples, blood cultures, thoracic computed tomography reports were reviewed from hospital charts and laboratory reports. A total of 220 patients were hospitalized in COVID-19 period compared to 205 admissions in preCOVID-19 period. The prevalence of candidemia was similar - $14 / 220$ patients $(6.3 \%)$ in 2020 vs $14 / 205$ $(6.8 \%)$ in 2019 . Lower respiratory tract fungal culture was sent from 27 vs 27 patients $(p=0.7)$, tracheal aspirate/bronchial lavage-GM from 17 vs 11 patients $(p=$ $0.17)$, serum GM from 28 vs 11 patients $(p=0.002)$ in 2019 and 2020, respectively. There was one case of IPA in pre-COVID-19 period compared to 4 cases in the last 6 months. Although this suggests a trend of increase in IPA, it did not reach a statistically significant level $(p=0.2)$ because of few cases (Table 1).

Table 1. Clinical features of patients with COVID-19 associated invasive pulmonary aspergillosis

\begin{tabular}{|c|c|c|c|c|}
\hline Patients & 1 & 2 & 3 & 4 \\
\hline Age & 55 & 80 & 51 & 54 \\
\hline Gender & Male & Female & Male & Male \\
\hline Comorbidities & Renal transplantation & $\begin{array}{c}\text { Hypertension } \\
\text { Good-Pasture Syndrome }\end{array}$ & $\begin{array}{l}\text { Diabetes, Hypertension } \\
\text { Renal transplantation } \\
\text { Ischemic heart disease }\end{array}$ & Bronchiectasis \\
\hline $\begin{array}{l}\text { Corticosteroids/ } \\
\text { immunosuppressive } \\
\text { therapy }\end{array}$ & $\begin{array}{l}\text { Methyl-prednisolone (Pulse } \\
\text { Methyl-prednisolone, } \\
\text { prednisolone, } \\
\text { mycophenolate mofetil prior } \\
\text { to COVID-19) }\end{array}$ & $\begin{array}{l}\text { Methyl-prednisolone } \\
\text { (Pulse Methyl- } \\
\text { prednisolone, } \\
\text { cyclophosphamide prior } \\
\text { to COVID-19) }\end{array}$ & $\begin{array}{l}\text { Methyl-prednisolone } \\
\text { (prednisolone, } \\
\text { tacrolimus, } \\
\text { mycophenolate mofetil } \\
\text { prior to COVID-19) }\end{array}$ & $\begin{array}{l}\text { Dexamethasone } \\
\text { Methyl- } \\
\text { prednisolone }\end{array}$ \\
\hline $\begin{array}{l}\text { PCR test result for } \\
\text { diagnosis of COVID-19 }\end{array}$ & $(+)$ & $(+)$ & $(+)$ & $(+)$ \\
\hline $\begin{array}{l}\text { Specific therapies for } \\
\text { COVID-19 }\end{array}$ & $\begin{array}{c}\text { Favipiravir, } \\
\text { hydroxychloroquine } \\
\text { Hemoadsorption therapy, } \\
\text { intravenous immunglobuline }\end{array}$ & $\begin{array}{c}\text { Favipiravir, } \\
\text { hydroxychloroquine, } \\
\text { Azithromycin, intravenous } \\
\text { immunglobuline }\end{array}$ & $\begin{array}{l}\text { Favipiravir, intravenous } \\
\text { immunglobuline }\end{array}$ & $\begin{array}{l}\text { Favipiravir, } \\
\text { Tocilizumab, } \\
\text { İnhaled nitric } \\
\text { oxide }\end{array}$ \\
\hline Timing of IPA $(* / \uparrow)$, days & $20 / 25$ & $4 / 4$ & $5 / 8$ & $16 / 29$ \\
\hline Mycology results & $\begin{array}{c}\text { ETA-GM-EIA: } 1.28 \\
\text { ETA-Fungal Culture: negative }\end{array}$ & $\begin{array}{c}\text { ETA-GM-EIA: } 15 \\
\text { Serum GM-EIA }(x 2): 0.79, \\
2.4\end{array}$ & $\begin{array}{l}\text { Serum GM-EIA }(\mathrm{x} 2) \text { : } \\
9.2,12 \\
\text { ETA-Fungal Culture: } \\
\text { negative }\end{array}$ & $\begin{array}{c}\text { Serum GM-EIA: } \\
3.2 \\
\text { ETA-Fungal } \\
\text { Culture: negative }\end{array}$ \\
\hline Radiology & $\begin{array}{c}\text { Non specific ground-glass } \\
\text { opacities }\end{array}$ & $\begin{array}{c}\text { Non specific ground-glass } \\
\text { opacities }\end{array}$ & Nodules, cavitation & Cavitation \\
\hline Antifungal agent & voriconazole & $\begin{array}{l}\text { voriconazole, } \\
\text { posaconazole }\end{array}$ & voriconazole & voriconazole \\
\hline Secondary infections & $\begin{array}{c}\text { CMV pneumonitis } \\
\text { Pseudomonas aeruginosa/ } \\
\text { Klebsiella pneumonia (ETA) }\end{array}$ & $\begin{array}{l}\text { Acinetobacter baumanni } \\
\text { (blood culture) }\end{array}$ & $\begin{array}{c}\text { Pseudomonas } \\
\text { aeruginosa (blood } \\
\text { culture) }\end{array}$ & $\begin{array}{l}\text { Acinetobacter } \\
\text { baumanni, } \\
\text { Enterococcus } \\
\text { faecalis (ETA) }\end{array}$ \\
\hline ICU mortality & Yes & Yes & Yes & No \\
\hline
\end{tabular}


Although less serum GM tests were performed, the number of patients with IPA was higher in the COVID19 period. Further data is needed to confirm this trend in prospective studies.

\section{REFERENCES}

1. Koehler P, Cornely OA, Bottiger BW, Dusse F, Eichenauer $D A$, Fuchs $F$, et al. COVID-19 associated pulmonary aspergillosis. Mycoses 2020; 63(6): 528-34.

2. Donnelly JP, Chen SC, Kauffman CA, Steinbach WJ, Baddley JW, Verweij PE, et al. Revision and update of the consensus definitions of invasive fungal disease from the European Organization for research and treatment of cancer and the Mycoses Study Group Education and Research Consortium. Clin Infect Dis 2020; 71(6): 1367-76.
3. Schauwvlieghe $A$, Rijnders BJA, Philips $N$, Verwijs $R$, Vanderbeke L, Van Tienen C, et al. Invasive aspergillosis in patients admitted to the intensive care unit with severe influenza: a retrospective cohort study. Lancet Respir Med 2018; 6(10): 782-92.

4. Bartoletti $M$, Pascale $R$, Cricca $M$, Rinaldi $M$, Maccaro $A$, Bussini L, et al. Epidemiology of invasive pulmonary aspergillosis among COVID-19 intubated patients: a prospective study. Clin Infect Dis 2020. Epub 2020 Jul 29.

5. White PL, Dhillon R, Cordey A, Hughes H, Faggian F, Soni $S$, et al. A national strategy to diagnose COVID-19 associated invasive fungal disease in the ICU. Clin Infect Dis 2020. Epub 2020 Aug 30. 